\title{
Hypoglycaemic and hypolipidaemic effects of crude extracts and chromatographic fractions of Morinda morindoides root bark in diabetic rats
}

\author{
Johnny Olufemi Olukunle ${ }^{1}$, Matthew Oluwole Abatan², Olubukola Tolulope Adenubi ${ }^{1}$, \\ Timothy Adeolu Amusan ${ }^{1}$ \\ ${ }^{1}$ University of Agriculture, College of Veterinary Medicine, Department of Veterinary Physiology and \\ Pharmacology, Abeokuta, Ogun State \\ ${ }^{2}$ University of Ibadan, Department of Veterinary Physiology, Biochemistry and Pharmacology, Ibadan, \\ Oyo State \\ Received January 13, 2012 \\ Accepted May 16, 2012
}

\begin{abstract}
Hypoglycaemic and hypolipidaemic effects of different extracts and fractions of root bark from the plant Morinda morindoides (Baker) Milne-Redh of the family Rubiaceae were evaluated in alloxan-induced diabetic rats. The aqueous and methanolic extracts were administered to 48 rats orally at a dose of $400 \mathrm{mg} \cdot \mathrm{kg}^{-1}$ for 21 days. Fractions (hydromethanol, hexane, chloroform and ethyl acetate) from bio-activity guided fractionation and chromatographic sub fractions $(C s F)$ A-F from accelerated gradient chromatography were also evaluated in 45 rats for the hypoglycaemic activity at doses of $400 \mathrm{mg} \cdot \mathrm{kg}^{-1}, 200 \mathrm{mg} \cdot \mathrm{kg}^{-1}$ and $100 \mathrm{mg} \cdot \mathrm{kg}^{-1}$ of solvent fractions and $(C s F) \mathrm{A}-\mathrm{F}$, respectively. Glibenclamide was used as positive control. Polyoxyethylene sorbitan monooleate and distilled water administered to rats were used as negative controls. The dose of $400 \mathrm{mg} \cdot \mathrm{kg}^{-1}$ of aqueous and methanolic extracts and $100 \mathrm{mg} \cdot \mathrm{kg}^{-1}$ of chloroform $C s F \mathrm{~B}$ of Morinda morindoides caused (62.8\%, 56\% and 74\%, respectively) reductions in blood glucose level (BGL). The aqueous extract caused significant $(P<0.05)$ decreases in the values of serum cholesterol $(133.48 \pm 1.1) \mathrm{mg} \cdot \mathrm{dl}^{-1}$, low density lipoprotein $(66.38 \pm 2.5) \mathrm{mg} \cdot \mathrm{dl}^{-1}$ and significant $(P<0.05)$ increase in the value of high density lipoprotein $(51.03 \pm 3.0) \mathrm{mg} \cdot \mathrm{dl}^{-1}$ when compared to the control. These results confirm the folkloric claim of the hypoglycaemic and hypolipidaemic activities of Morinda morindoides root bark.
\end{abstract}

Antidiabetic, lipid lowering, medicinal plants

Diabetes mellitus which causes hyperglycaemia is a disease caused by insufficient insulin production by the pancreatic $\beta$ cells or inability of the body to utilize insulin due to the peripheral tissue resistance. This leads to a serious damage of many parts of the body's systems, especially nerves and blood vessels (WHO 2010).

The chemical agents used in the treatment of diabetes mellitus type 2 are expensive and could lead to adverse side effects. Development of alternative strategies for the prevention and treatment of diabetes is therefore necessary especially in countries with poor economy (Fertig et al. 1995).

Morinda morindoides (Baker) Milne-Redh of the family Rubiaceae has medicinal application in some African countries, especially in Nigeria, where it is used for the treatment of different diseases. It is called brimstone tree in English and "oju ologbo" in Yoruba (Southwest, Nigeria). M. morindoides is used in the form of infusion against malaria (Tona et al. 2001), diarrhoea, haemorrhoids, gonorrhoea, amoebiasis and rheumatism (Kambu 1990; Tona et al. 1999; Cimanga et al. 2006). The extract from root bark is used for the treatment of diabetes mellitus in South Western part of Nigeria.

Though many studies have been carried out on the leaf extract of this plant, less work has been done on the root bark extract in the treatment of diabetes mellitus as claimed by the traditional healers in Southwest Nigeria. This study is therefore aimed at investigating the hypoglycaemic and hypolipidaemic properties of aqueous and methanol extracts, and the bioactive solvent chromatographic sub fractions of $M$. morindoides root bark in alloxan-induced diabetic rats.

Address for correspondence:

Johnny Olufemi Olukunle

Department of Veterinary Physiology and Pharmacology

College of Veterinary Medicine

University of Agriculture, Abeokuta, Ogun State

Phone: $+234-8101846078$

E-mail: drfaks@yahoo.com

http://actavet.vfu.cz/ 


\section{Materials and Methods}

Plant material and preparation of extract

Fresh root bark of Morinda morindoides was identified at the Forestry Research Institute of Nigeria (F.R.I.N), Ibadan, and Botany Department, College of Natural Sciences, University of Agriculture, Abeokuta, Nigeria where a specimen was deposited.

Five hundred grams of the root bark were air-dried, pulverized and soaked in 21 of distilled water for $48 \mathrm{~h}$, filtered and freeze-dried. Then, two kilograms of the air-dried and pulverized root bark were soaked in 51 of methanol for $72 \mathrm{~h}$ and concentrated at $55^{\circ} \mathrm{C}$ in water bath. The samples were stored at $-4{ }^{\circ} \mathrm{C}$ until the experiment.

Two grams of the freeze-dried solid M. morindoides were dissolved in $20 \mathrm{ml}$ of distilled water $\left(100 \mathrm{mg} \cdot \mathrm{ml}^{-1}\right)$. Two $\mathrm{g}$ of the solid residue from concentrated methanol filtrate were dissolved in $20 \mathrm{ml}$ of Tween-80 $\left(100 \mathrm{mg} \cdot \mathrm{ml}^{-1}\right)$. These solutions were used for administration to the rats.

Bio-activity guided fractionation

One hundred grams of the crude methanol extract of the root bark $M$. morindoides were suspended in $1: 3$ ratio with methanol-water mixture (hydromethanol), -n-Hexane, -chloroform, and -ethyl acetate. This dilution was done in a separatory funnel at each stage. The organic fractions (phases) were collected and the solvent was removed by concentrating the fraction in water bath at $55^{\circ} \mathrm{C}$. This procedure was carried out for all n-Hexane, chloroform, ethyl acetate and $\mathrm{MeOH}$. The bioactive solvent-fractions were subjected to purification by further fractionation using a standard procedure of accelerated gradient chromatography (Svoronos and Sarlo 1993) and the chromatographic sub-fractions were pooled into six (A-F) according to their TLC. All fractions and reference glibenclamide were suspended in Tween-80 and used for oral administration to the rats.

\section{Animals}

Ninety three, 8-10 week-old Wistar rats of both sexes, weighing 150-200 g were provided with rodent feed from Vital feeds Limited, Ibadan, Nigeria and supplied with water ad libitum. The animals were acclimatized to laboratory conditions for two weeks before the experiment with controlled lighting of $12: 12 \mathrm{~h}$ of light : dark cycles, temperature of $26 \pm 2{ }^{\circ} \mathrm{C}$ and relative humidity of $55 \%$.

\section{Induction of diabetes mellitus}

The fasting blood glucose levels were measured at intervals of $30 \mathrm{~min}, 1 \mathrm{~h}, 2 \mathrm{~h}, 4 \mathrm{~h}, 6 \mathrm{~h}, 8 \mathrm{~h}$ and $24 \mathrm{~h}$ after a single dose of the extract and glibenclamide in rats. Diabetes mellitus was induced by a single injection of 5\% alloxan monohydrate (Sigma-Aldrich, Belgium) at a dose rate of $125 \mathrm{mg} \cdot \mathrm{kg}^{-1}$ intraperitoneally (Trivedi et al. 2004). Diabetes mellitus was confirmed after $48 \mathrm{~h}$. Only rats with blood glucose level of $150 \mathrm{mg} \cdot \mathrm{dl}^{-1}$ and more were included in the study. The control group of rats was injected with normal saline intraperitoneally. The third day to the alloxan injection was taken as Day 0 . The rats were fasted for $12 \mathrm{~h}$ before the experiment but were allowed unrestricted access to water. Polyoxyethylene sorbitan monooleate (Tween 80, Sigma-Aldrich, Belgium) was administered orally as delivery vehicle for the plant extract, glibenclamide (Nigerian-German Chemical PLC) and the negative control group.

Effect of multiple administration of aqueous extract of $M$. morindoides on blood glucose level and lipids - Experiment 1

The animals were divided into 4 groups of 6 rats in one group. Group 1 included diabetic rats administered $400 \mathrm{mg} \cdot \mathrm{kg}^{-1}$ of aqueous extract of $M$. morindoides; Group 2 included diabetic rats administered $10 \mathrm{mg} \cdot \mathrm{kg}^{-1} \mathrm{of}$ glibenclamide; Group 3 included diabetic rats given distilled water at $10 \mathrm{ml} \cdot \mathrm{kg}^{-1}$ and Group 4 included control rats (non-diabetic) administered $10 \mathrm{ml} \cdot \mathrm{kg}^{-1}$ of distilled water orally. All administration was done once daily for 21 days and the blood glucose level was measured at Day 0 and at Day 21.

The serum cholesterol, triglycerides, the high density lipoprotein (HDL) and low density lipoprotein (LDL) were also measured at Day 21 from blood collected from the retro-orbital plexus of ether-anaesthetized rats using standard procedures (Bucolo and David 1973; Allain et al. 1974).

The effect of single dose of the methanol extract of $M$. morindoides in rats - Experiment 2

Rats used for this experiment were as described above except for Group 1 that included diabetic rats administered $400 \mathrm{mg} \cdot \mathrm{kg}^{-1}$ methanol extract of $M$. morindoides and Group 4 of rats administered $5 \mathrm{ml} \cdot \mathrm{kg}^{-1} \mathrm{Tween}-80$ serving as control; all 4 groups were treated only once. The fasting blood glucose levels were measured at intervals of 30 min, $1 \mathrm{~h}, 2 \mathrm{~h}, 4 \mathrm{~h}, 6 \mathrm{~h}, 8 \mathrm{~h}$ and $24 \mathrm{~h}$ after the administration. The percentage change in BGL was calculated using following equation:

$\%$ change in $\mathrm{BGL}=\frac{\mathrm{Vx}-\mathrm{Vo}_{\mathrm{O}}}{\mathrm{Vo}_{\mathrm{O}}} \times 100$

where

Vo is the BG values at $0 \mathrm{~h}$,

Vx are the BG values at $30 \mathrm{~min}, 1 \mathrm{~h}, 2 \mathrm{~h}, 4 \mathrm{~h}, 6 \mathrm{~h}, 8 \mathrm{~h}$ and $24 \mathrm{~h}$, respectively (Fuentes et al. 2004). 
Hypoglycaemic effect of the chromatographic fractions of $M$. morindoides - Experiment 3

In this experiment, 9 groups of 5 rats per group were used with Groups 1-8 consisting of diabetic rats and Group 9 consisting of non-diabetic rats. Groups $1-6$ were given $100 \mathrm{mg} \cdot \mathrm{kg}^{-1}$ of the chromatographic sub-factions $(C s F)$ A-F. Rats in Group 7 were treated with $10 \mathrm{mg} \cdot \mathrm{kg}^{-1}$ glibenclamide and Groups $8-9$ rats were given Tween-80 at a dose of $5 \mathrm{ml} \cdot \mathrm{kg}^{-1}$ body weight. The fasting blood glucose levels were measured at intervals of $30 \mathrm{~min}, 1 \mathrm{~h}, 2$ $\mathrm{h}, 4 \mathrm{~h}, 6 \mathrm{~h}, 8 \mathrm{~h}$ and $24 \mathrm{~h}$ after the administration.

Statistical analysis

Results were expressed as mean \pm SEM. Analysis of the data was done using the one-way Analysis of Variance (ANOVA) followed by the Duncan multiple range test. $P$ value $<0.05$ was considered significant in all cases.

\section{Results}

Effect of multiple administration of aqueous extract of $M$. morindoides on BGL and lipids

After 21 days of treatment, there was a significant $(P<0.05)$ reduction in blood glucose level of the rats treated with $400 \mathrm{mg} \cdot \mathrm{kg}^{-1}$ aqueous extract of $M$. morindoides $(62.9 \%$ reduction in BGL). The group of rats treated with $10 \mathrm{mg} \cdot \mathrm{kg}^{-1}$ of glibenclamide showed a significant $(P<0.05)$ decrease in the blood glucose level $(63.2 \%$ reduction $)$ after 21 days of treatment compared to the control rats with $269.50 \pm 10.6 \mathrm{mg} \cdot \mathrm{dl}^{-1}$ at day 0 to $324.53 \pm$ $22.3 \mathrm{mg} \cdot \mathrm{dl}^{-1}$ at day 21 ( $20.1 \%$ increase in BGL) (Table 1$)$.

The extract also caused significant $(P<0.05)$ decreases in serum cholesterol $(133.48$ $\pm 1.1) \mathrm{mg} \cdot \mathrm{dl}^{-1}$ and serum low density lipoproteins $(66.38 \pm 2.5) \mathrm{mg} \cdot \mathrm{dl}^{-1}$ and significant $(P<0.05)$ increase in serum high-density lipoprotein value $(51.03 \pm 3.0) \mathrm{mg} \cdot \mathrm{dl}^{-1}$. Glibenclamide $\left(10 \mathrm{mg} \cdot \mathrm{kg}^{-1}\right)$ caused a significant $(P<0.05)$ reduction in the serum cholesterol $(134.13 \pm 1.5) \mathrm{mg} \cdot \mathrm{dl}^{-1}$, low-density lipoprotein $(68.70 \pm 3.5) \mathrm{mg} \cdot \mathrm{dl}^{-1}$ and significant $(P<0.05)$ increase in the serum high-density lipoproteins $(47.32 \pm 2.2) \mathrm{mg} \cdot \mathrm{dl}^{-1}$ after 21 days post treatment when compared to the values from rats in the untreated diabetic control group (Table 1).

\section{Effect of single dose methanolic extract of $M$. morindoides}

Methanolic extracts of Morinda morindiodes at a single dose of $400 \mathrm{mg} \cdot \mathrm{kg}^{-1}$ body weight produced a significant $(P<0.05)$ reductions in the blood glucose level of the rats at $1 \mathrm{~h}, 2 \mathrm{~h}$, $4 \mathrm{~h}, 6 \mathrm{~h}, 8 \mathrm{~h}$ and $24 \mathrm{~h}$ post treatments (Table 2). The percentage hourly reductions in blood glucose level were from $2.5 \%$ in $30 \mathrm{~min}$ to $17.7 \%, 33.1 \%, 45.9 \%, 40.4 \%$ and $41.8 \%$ in $1 \mathrm{~h}, 2 \mathrm{~h}, 4 \mathrm{~h}, 6 \mathrm{~h}, 8 \mathrm{~h}$ and $24 \mathrm{~h}$, respectively. The extract produced a significant reduction $(P<0.05)$ of BGL $(56 \%)$ at the $24^{\text {th }} \mathrm{h}$ after treatment when compared to the untreated diabetic control group (Table 2).

Group of rats dosed with $10 \mathrm{mg} \cdot \mathrm{kg}^{-1}$ glibenclamide showed percentage hourly reduction of the BGL of $6.2 \%, 22.5 \%, 27.1 \%, 33.4 \%, 23.3 \%, 24.8 \%$ and $52.4 \%$ at 30

Table 1. Effects of $400 \mathrm{mg} \cdot \mathrm{kg}^{-1}$ dose of the aqueous extract of Morinda morindoides root bark in alloxan-induced diabetic rats (mean \pm standard error of mean)

\begin{tabular}{lccccccc}
\hline $\begin{array}{l}\text { Groups } \\
(\mathrm{n}=6)\end{array}$ & $\begin{array}{c}\text { Blood glucose } \\
\left(\mathrm{mg} \cdot \mathrm{dl}^{-1}\right)\end{array}$ & $\begin{array}{c}\text { Blood glucose } \\
\left(\mathrm{mg} \cdot \mathrm{dl}^{-1}\right)\end{array}$ & $\begin{array}{c}\text { \% Change in } \\
\text { blood glucose } \\
\text { level }(\%)\end{array}$ & $\begin{array}{c}\text { Cholesterol } \\
\left(\mathrm{mg} \cdot \mathrm{dl}^{-1}\right)\end{array}$ & $\begin{array}{c}\text { TRIG } \\
\left(\mathrm{mg} \cdot \mathrm{dl}^{-1}\right)\end{array}$ & $\begin{array}{c}\text { HDL }\left(\mathrm{mg} \cdot \mathrm{dl}^{-1}\right) \\
\text { Day 21 }\end{array}$ & $\begin{array}{c}\text { LDL }\left(\mathrm{mg} \cdot \mathrm{dl}^{-1}\right) \\
\text { Day 21 }\end{array}$ \\
\hline Group 1 & $277.87 \pm 17.5$ & $103.00 \pm 20.0^{*}$ & -62.9 & $133.48 \pm 1.1^{*}$ & $80.00 \pm 4.6$ & $51.03 \pm 3.0^{*}$ & $66.38 \pm 2.5^{*}$ \\
Group 2 & $268.63 \pm 14.8$ & $98.85 \pm 2.9^{*}$ & -63.2 & $134.13 \pm 1.5^{*}$ & $86.45 \pm 4.5$ & $47.32 \pm 2.2^{*}$ & $68.70 \pm 3.5^{*}$ \\
Group 3 & $269.50 \pm 10.6$ & $324.53 \pm 22.3$ & +20.1 & $159.62 \pm 2.6$ & $91.87 \pm 4.8$ & $25.70 \pm 0.9$ & $116.98 \pm 3.0$ \\
Group 4 & $113.18 \pm 2.3$ & $108.00 \pm 3.1$ & -4.6 & $128.82 \pm 4.1^{*}$ & $83.90 \pm 4.3$ & $40.80 \pm 2.5^{*}$ & $69.08 \pm 4.9^{*}$ \\
\hline
\end{tabular}

Group 1 - Morinda morindoides, Group 2 - glibenclamide, Group 3 - untreated diabetic, Group 4 - non-diabetic * Superscripted figures are significant at $P<0.05$, value in \% implies decrease in blood glucose level (BGL) TRIG - triglycerides, HDL - high density lipoprotein, LDL - low density lipoprotein 


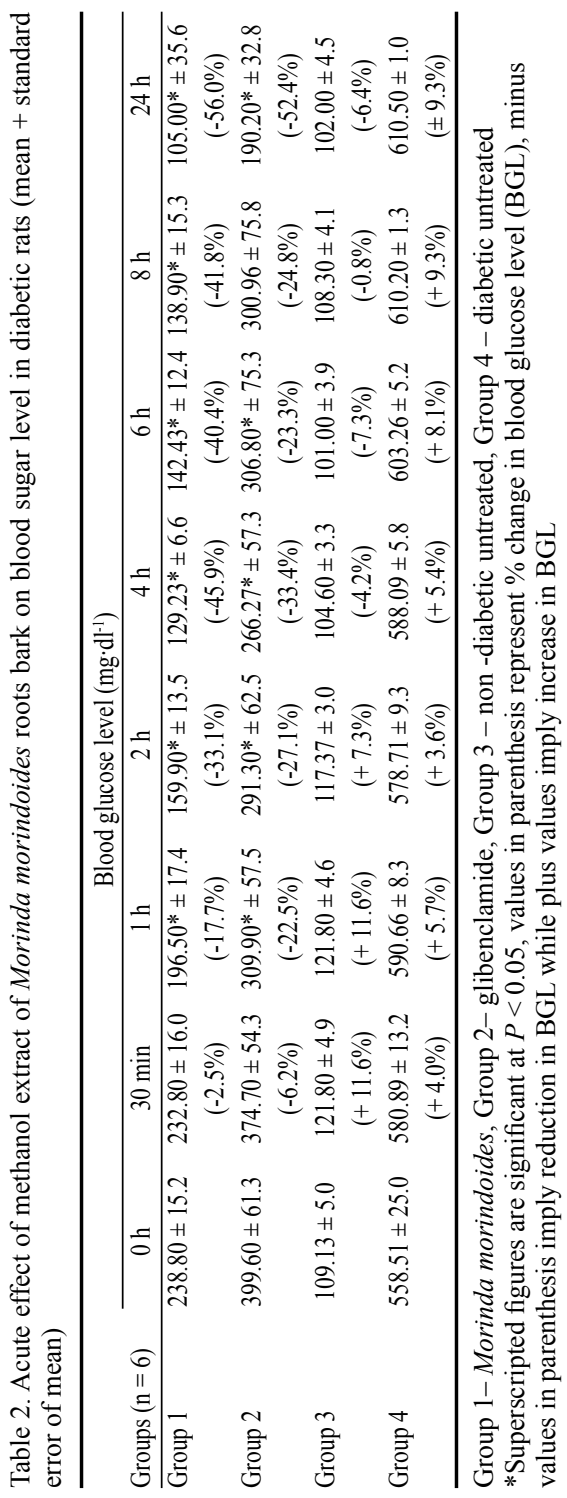

min, $1 \mathrm{~h}, 2 \mathrm{~h}, 4 \mathrm{~h}, 6 \mathrm{~h}, 8 \mathrm{~h}$ and $24 \mathrm{~h}$, respectively (Table 2 ).

Hypoglycaemic effect of solvent fractions of $M$. morindoides

Administration of the 400 and 200 $\mathrm{mg} \mathrm{kg}^{-1}$ chloroform fractions had the highest hypoglycaemic activity with percentage BGL change of $0.3 \%$ and $2.5 \%$, respectively, at $30 \mathrm{~min}$ and

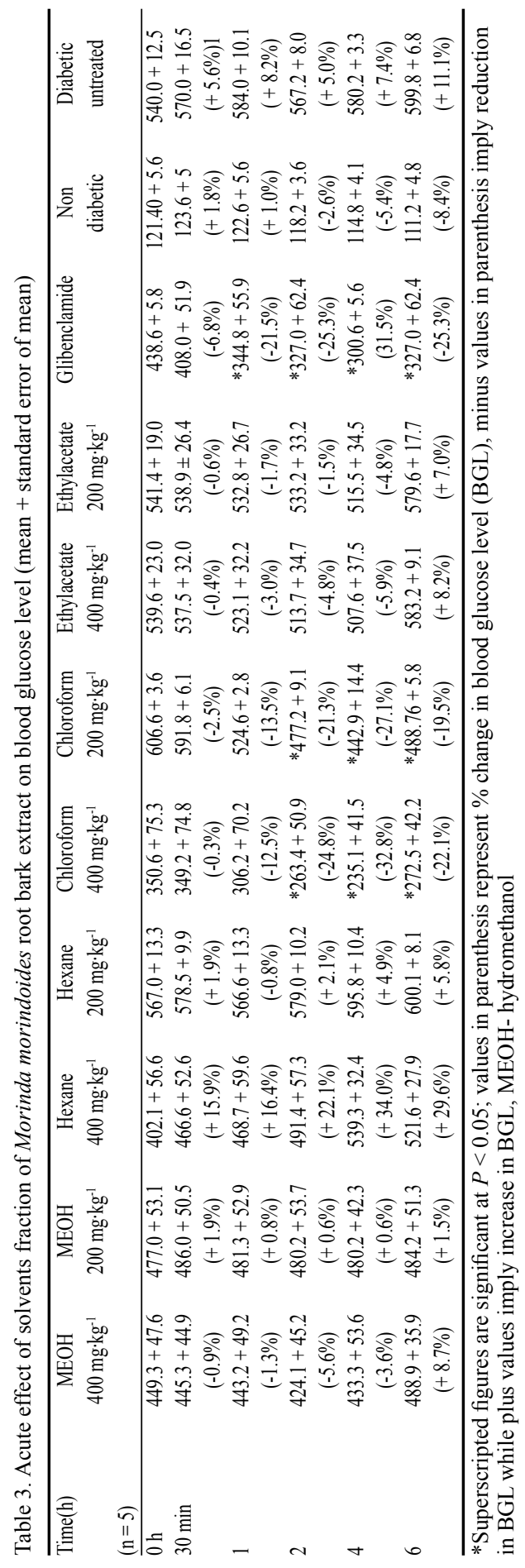


$12.5 \%$ and $13.5 \%, 24.8 \%$ and $21.3 \%, 32.8 \%$ and $27.1 \%$ and $22.1 \%$ and $19.5 \%$ at $1 \mathrm{~h}, 2 \mathrm{~h}$, $4 \mathrm{~h}$ and $6 \mathrm{~h}$, respectively, after treatment. These values are comparable to results from the group given glibenclamide (Table 3 ).

\section{Hypoglycaemic effect of the chromatographic fractions}

of M. morindoides

For the A-F (6) chloroform chromatographic sub-fractions of M. morindoides at 100 $\mathrm{mg} \cdot \mathrm{kg}^{-1}$, sub-fraction B showed the highest activity of $472.8 \pm 57 \mathrm{mg} \cdot \mathrm{dl}^{-1}$ blood sugar reduction at $0 \mathrm{~h}$ to $218.9 \pm 65 \mathrm{mg} \cdot \mathrm{dl}^{-1}$ at $4 \mathrm{~h}$ and then to $121.2 \pm 13.4 \mathrm{mg} \cdot \mathrm{dl}^{-1}, 24 \mathrm{~h}$ post administration (Table 4). This implies a $53.7 \%$ and $74.4 \%$ reduction of blood glucose, respectively (Table

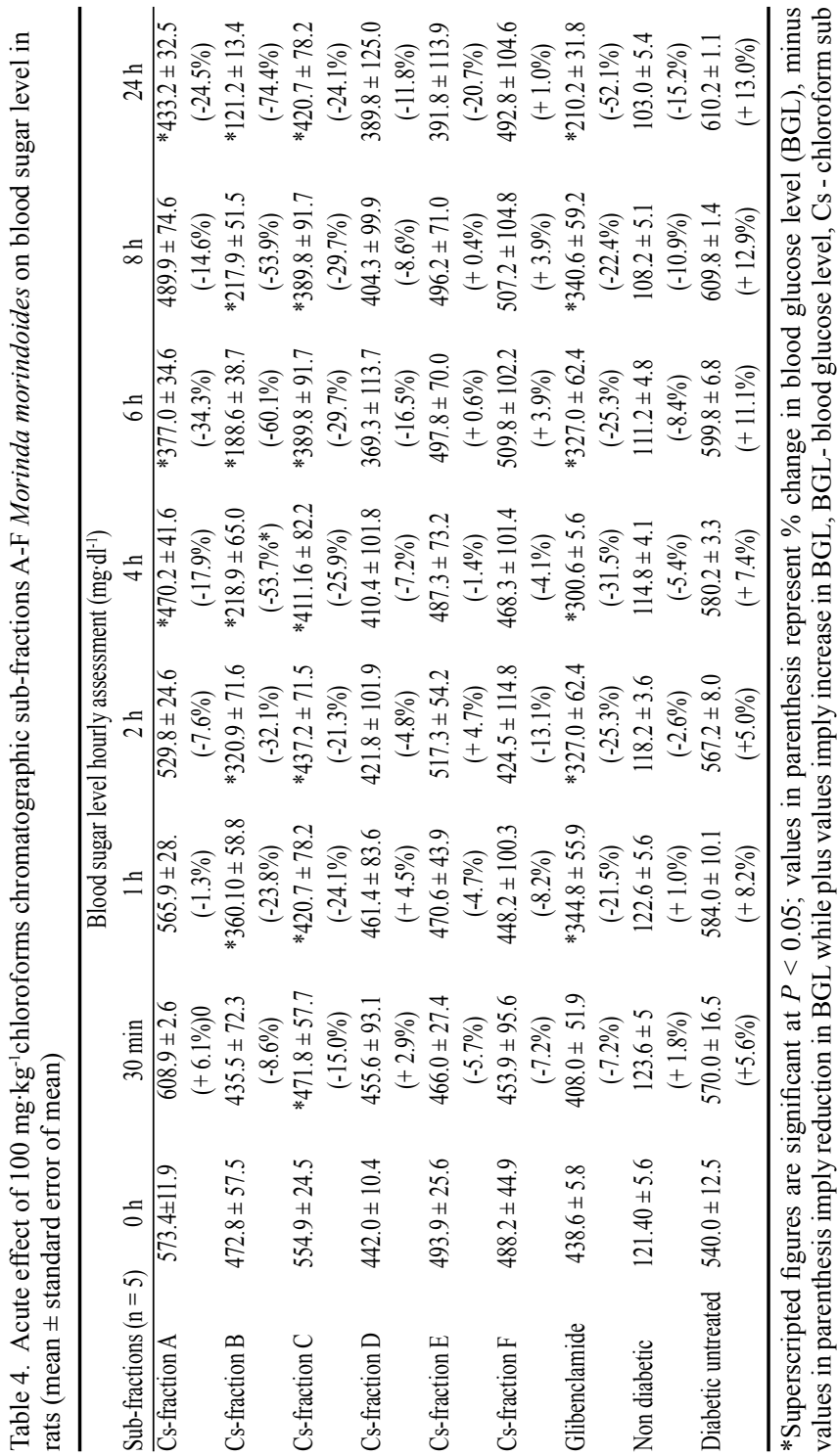

4). These values are higher than that obtained for the glibenclamide group with blood glucose level from $(438.6 \pm 5.8) \mathrm{mg} \cdot \mathrm{dl}^{-1}$ at 0 $\mathrm{h}$ to $(300.6 \pm 5.6) \mathrm{mg} \cdot \mathrm{dl}^{-1}$ at $4 \mathrm{~h}$ and to $(210.2 \pm$ $31.8) \mathrm{mg} \cdot \mathrm{dl}^{-1}$ at $24 \mathrm{~h}$ post administration implying $(31.5 \%$ and $52.1 \%$, respectively) (Table 4).

\section{Discussion}

In this study, the hypoglycaemic and hypolipidaemic activities of the crude aqueous extract, solvent fractions and chromatographic sub-fractions of $M$. morindoides were evaluated in alloxan-induced diabetic rats. The 21-day treatment with aqueous extract of $M$. morindoides caused a significant decrease in the blood glucose of hyperglycaemic rats, and in serum triglyceride, cholesterol and LDL while increasing the serum HDL level. These effects were comparable to those obtained for glibenclamide a standard anti diabetic agent.

It was also observed that the methanol extract of $M$. morindoides caused significant reduction in blood glucose levels compared to glibenclamide. It was further observed that 
the hypoglycaemic effect of the chloroform fraction $M$. morindoides was higher than that of glibenclamide. This may suggest that the extract of $M$. morindoides is anti-diabetic as WHO (2010) associated the treatment of diabetes with the lowering of blood glucose and the concentrations of other known risk factors that damage blood vessels and nervous tissues. Plants such as Laportea ovaliofolia have been reported to be anti-diabetic as they cause the reduction of blood glucose level and serum lipids of diabetic animals (Momoh et al. 2006). The hypoglycaemic and hypolipidaemic actions of $M$. morindoides may be similar to those of insulin because insulin is hypoglycaemic and lowers lipid levels (Ahmed et al. 2001). The hypoglycaemic activity of $M$. morindoides may be attributable to its flavonoids content and flavonoid o-glycosides (Cimanga et al. 1995; Harisolo et al. 2009). Flavonoids are reported to potentiate the increase of pancreatic secretion of insulin from $\beta$-cells and to increase the peripheral utilization of glucose. Ves sal et al. (2003), reported that quercetin, a flavonoid with antioxidant properties brings about the regeneration of the pancreatic islets and probably increases insulin release in streptozocin-induced diabetic rats. This study suggests the hypoglycaemic and hypolipidaemic potential of Morinda morindoides.

\section{References}

Ahmed I, Lakhani MS, Gillett M, John A, Raza H 2001: Hypotriglyceridemic and hypocholesterolemic effetcs of anti-diabetic Momordica charantia (karela) fruit extract in streptozotocin-induced diabetic rats. Diabetes Res Clin Pract 51: 155-161

Allain CC, Poon LS, Chan CS, Richmond W, Fu PC 1974: Enzymatic determination of total serum cholesterol. Clin Chem 20: 470-4755

Bucolo G, David H 1973: Quantitative determination of serum triglycerides by the use of enzymes. Clin Chem 19: $476-482$

Cimanga K, De Bruyne T, Lasure A, Van Poel B, Pieters L, Vanden Berghe D, Vietnck A, Kambu K, Tona L 1995: In vitro anticomplementary activity of constituents from Morinda morindoides. J Nat Prod 58: $372-378$

Cimanga RK, Kambu K, Tona L, Hermans N, Apers S, Totte J, Pieters L, Vlietinck AJ 2006: Citotoxicity and invitro susceptibility of Entamoeba histolytica to Morinda morindoides leaf extract and its isolated constituents. J Ethnopharm 107: 83-90

Fertig BJ, Simmon SDA, Marten MB 1995: Therapy for diabetes. Diabetes 95: 1468-1469

Fuentes O, Arancibis A, Alarcon H 2004: Hypoglycemic activity of Bauhinia candican in diabetic induced rabbits. Fitoterapia 6: 527-532

Harisolo R, Chardin SS, Philomène AY, Timothé O, Vincent AA, Léon AD, Antoin AC 2009: A ketosteroid isolated from Morinda morindoides. Europ J Sci Res 28: 621-626

Kambu K 1990: Elements de phytotherapic compance plants medicinales Africanes CRP-Kinshasa 20-22

Momoh CE, Oben JE, Tazoo D, Dongo E 2006: Antidiabetic and hypolipidaemic effects of a methanol/methylenechloride extract of Laportea ovalifolia (Urticaceae), measured in rats with alloxan-induced diabetes. A Trop Med Parasitol 100: 69-74

Nagappa AN, Thakurdesai PA, Venkat Raob N, Jiwan S 2003: Antidiabetic activity of Terminalia catappa Linn fruits. J Ethnopharm 88: 45-50

Svoronos P, Sarlo E 1993: Separation of methylene blue and fluorescein: a microscale undergraduate experiment in column chromatography. J Chem Educ 70: 158-159

Tona L, Kambu K, Mesia K, Cimanga RK, Apres S, De Bruyne T, Pieters L, Totte J, Vlietnick AJ 1999: Biological screening of traditional preparations from some medicinal plants used as antidiarrhoeal in Kinshasa, Congo Phytomedicine 6: 59-66

Tona L, Mesia K, Ngimbi NP, Chrimwami Okond'Ahoka B, Cimanga K, De Bruyne T, Hermans N, Totte J, Pieters L, Vlietnick AJ 2001: In-vivo antimalarial activity of Cassia occidentalis, Morinda morindoides and Phyllanthus niruri. A Trop Med Parasitol 95: 45-57

Trivedi NA, Mazumdar B, Bhatt JD, Hemavath KG 2004: Effect of shilajit on blood glucose and lipid profile in alloxan induced diabetic rats. Indian J Pharmacol 36: 373-376

Vessal M, Hemmati M, Vasei M 2003: Antidiabetic effects of quercetin in streptozocin-induced diabetic rats. Comp Biochem Physiol C Toxicol Pharmacol 135: 357-64

WHO 2010: Fact sheet No. 312 'Diabetes' Available at http://www.who.int/mediacentre/factsheets/fs312/en/ (accessed Apr 2010) 